\title{
A FURTHER CONTRIBUTION TO OUR KNOWLEDGE OF THE GENUS CHLORITIS, WITII DESGRIPTIONS OF ELEVEN NEW SPECIES.
}

\author{
By G. K. GUDE, F.Z.S.
}

Read 11th January, 1907.

PLATE XXI.

As interesting collection of shells from Australia and the Solomon Islands, sent over by Dr. J. C. Cox, was received by Mr. J. H. Ponsonby on the ere of his departure for an extended tour to the Far East, and has been placed in my hands for examination. This collection contains, besides a number of interesting specimens of known forms, no less than eight new species of Chloritis. A new species of this genus from New Guinea has also been submitted to me for description by Mrr. Ponsonby. Moreover, my own collection has contributed two others, both received from the collection of the late Mr. C. E. Beddome; these were accompanied by labels bearing MIr. Brazier's manuscript names and marked "ex auct." I have adopted these names, as no doubt the shells, so labelled, exist in other collections. At the same time, however, I enter a protest against the bestowal of manuscript names, which gires rise to confusion and is an ill service to science.

I take this opportunity of referring to the opinion expressed by the late Mr. Ancey ${ }^{1}$ that Chloritis Malangensis, Bullen, described as from $\mathrm{Jara}^{2}{ }^{2}$ is probabls identical with Mroellendorffia eucharistus, Pilsbry, from Loo Choo. Mr. Bullen has obligingly allowed me to inspect his types of $C$. Mlalangensis, and on comparing them with Pilsbry's species I find that they are certainly identical. C. Malangensis must therefore be reduced to a synonym of Moellendorffia eucharistus, and, as the locality Jara is almost certainly erroncous, this habitat must be deleted. The mistake arose most probably, as already suggested by Mr. Ances, through Mr. Roujer, from whom Mr. Bullen's shells were received.

Among the shells sent orer by Dr. Cox the following call for remark :-

1. A sinistral specimen of $C$. eustoma from the Solomon Islands.

2. A dead and worn specimen of the rery rare $C$. Beatricis, from British New Guinea. I hare seen only one other, which is in the collection of Colonel Beddome.

3. A large elerated form of C. quercina, measuring: diam. maj. 37, min. $31 \mathrm{~mm}$; ; alt. $33 \mathrm{~mm}$.

$\ddot{H a b}$. - Shortland Island, Solomon Islands.

1 Journ. de Conchyl., vol. liv (1906), p. 128.

2 Proc. Malac. Soc., rol. ri (1905), p. 192, pl. xi, fig. 2. 
4. C. quercina, rar. Mombroni, from Florida Island. An extraordinary pyramidal form, the last three whorls planate abore, flattened below, obtusely keeled, the keel exserted in all but the last $\frac{2}{3}$ whorl. Suture superficial. Diam. maj. 37.5 , min. $32 \mathrm{~mm}$; alt. $24 \mathrm{~mm}$.

- Both the type and the rariety are represented by bipartite specimens, with the upper side ochreous-brown, the lower straw-yellow.

5. C. Challengeri, Brron Bay, New South Wales. A new habitat. One other specimen is labelled Clarence and Richmond Rivers.

6. C. Norocambrica, an elerated form, labelled "Scrubs 8 miles from the North Pine River, Queensland." A new habitat, the type being described from New South Wales. Diam. maj. 15, min. $12.5 \mathrm{~mm}$.; alt. $11.5 \mathrm{~mm}$. A second specimen measures: diam. maj. 12, min. $10 \mathrm{~mm}$. ; alt. $8.5 \mathrm{~mm}$.

In my former paper, on p. 116, the references to $C$. Marimberti and C. Balansai, rar. cincta, have by a printer's crror unfortunately been transposed in the footnotes Nos. 2 and 3.

\section{DESCRIPTIONS OF NEW SPECIES.}

Chloritis coxomprata, n.sp. Pl. XXI, Figs. 1, $a-d$.

Shell widely umbilicated, depressed globose, distinctly and regularly striated, pale ochreous, the last whorl pale fulrous, corered with sparse hair-scars arranged in quincunx. Spire low, subplanate, apex immersed, suture deep. Whorls $4 \frac{1}{2}$, conrex, increasing regularly, the last somewhat suddenly, slowly descending and shortly deflexed in front, a little dilated at the mouth, obtusely angulated round the funnel-shaped umbilicus, which shows the entire penultimate whorl within. Aperture subcircular, little oblique, the margins convergent, united by a thin callus, peristome rosy-fulrous, thickened, shortly expanded and reflexed; upper margin arcuate, outer and basal rounded, columellar slightly dilated abore, impinging upon the umbilicus. Major diam. $21 \cdot 5$, min. $17 \cdot 5 \mathrm{~mm}$.; alt. $14 \mathrm{~mm}$.

IIab.- Rubiana, Solomon Islands.

TJpe in Dr. Cox's collection. Allied to C. discordialis, but smaller and with the hair-scars much more sparsely placed; the peristome is less expanded, the last whorl less dilated, and the aperture consequently smaller; the last whorl also descends less, and the umbilicus is not so widely excavated. A second specimen measures: major diam. 20, min. $16.5 \mathrm{~mm}$. ; alt. $12.5 \mathrm{~mm}$.

Cinloritrs uUnd, n.sp. Pl. XXI, Figs. 2, $a-d$.

Shell moderately umbilicated, discoid, dull, dark cinnamon brown, finely irregularly striated, the nepionic $1 \frac{1}{2}$ whorls minutely granulated; corered with distant small warty tubercles (probably bearing hairs when fresh) arranged in quincunx. Spire planate, apex almost immersed, suture deep. Whorls $4 \frac{1}{2}$, convex, increasing regularly, the last rather suddenly, a little dilated towards the mouth, rery slightly descending in front, slightly compressed below, and obtusely angulated round the slightly excavated umbilicus. Aperture ovate-lunate, oblique, margins conrergent; peristome thin, fulrous, upper and outer 
margins almost straight, the basal slightly reflexed, columellar triangularly dilated above and slightly orerhanging the umbilicus. Diam. maj. $12 \cdot 5$, min. $11 \cdot 25 \mathrm{~mm}$.; alt. $7 \cdot 75 \mathrm{~mm}$.

Mab.-Woon Creek, Burnett River watershed, Queensland.

Type in Dr. Cox's collection. At first I considered this to be C. spine $i$, but that species appears to have a rider unbilicus and more tumid whorls. A second specimen is immature, having only three whorls completed. The warty tubercles probably bear hairs or bristles when the shell is in fresh condition.

Culonitis lanuarosa, n.sp. Pl. XXI, Figs. $3, a-d$.

Shell narrowly umbilicated, depressed turbinate, dull corneous, finely striated, with microscopic spirals under a densely, shortly pilose cuticle, giving the shell a relrety appearance. Spire conoid, apex prominent, suture rather deep. Whorls $4 \frac{1}{2}$, convex, increasing regularly, the last a little widened and but slightly constricted behind the peristome, shortly deflexed in front, obscurely angulated round the narrow umbilicus. A perture suborate, oblique, margins convergent, united by a thin callus; peristome thin, slightly expanded, not reflexed; margins evenls rounded, columcllar triangularly dilated abore and reflexed orer the umbilicus. Diam. maj. 11, min. $9.5 \mathrm{~mm}$.; alt. $7.5 \mathrm{~mm}$.

Hab.-Eidsrold, Quecnsland.

Type in Dr. Cox's collection. This new species can only be compared to C. brevipila, but the whorls are less globose than in that species, the spire is more elerated, the last rhorl descends less in front, and the conspicuous bristles of $C$. brevipila are here absent; the margins of the peristome are also more distant. Under a very strong lens the quincuncial arrangement of the pili can with difficulty be detected on the earlier whorls, but on the last it is imperceptible.

Cnloritis fxilis, n.sp. Pl. XXI, Figs. 4, $a-d$.

Shell umbilicate, turbinate, very finely and regularly striated, dull, pale corneous, densely corered with minute soft, short, pale bristles arranged in quincunx. Spire conoid, apex obtuse, suture rather deep. Whorls 5, conrex, increasing rapidly, last dilated towards the mouth, slightly descending in front, obtusely angulated round the narrow umbilicus. A perture suboval, oblique, margins convergent; peristome white, scarcely thickened and narrowly reflexed, margins erenly rounded, columellar triangularly dilated and less than half corering the umbilicus. Diam. maj. 18 , min. $15 \mathrm{~mm}$; alt. $13.5 \mathrm{~mm}$.

Hab.-Mount Dryander, Port Denison, Queensland.

Type in Dr. Cox's collection. From $C$. Coxeni, its nearest ally, this new species is distinguished by its smaller size, the less covered umbilicus, and the densely crowded, finer, shorter, and paler bristles.

From C. Bennetti, another ally, it differs in the narrower umbilicus, and, although larger, in having one whorl less. A second specimen of this new species is paler, and possesses half a whorl less than the type. A third from Warroo, Port Curtis, is a little more elevated in the spire, measuring alt. $15 \mathrm{~mm}$. 
Chloriris coasats, n.sp. Pl. XXI, Figs. $5, a-d$. ,

Shell moderately umbilicate, globose turbinate, finely regularly - striated, whitish corneous, covered with crowded hair-scars arranged in quincunx. Spire conoid, apex obtuse, suture deep, almost channelled. Whorls nearly 5, convex, increasing regularly, the last rather suddenly, shortly deflexed in front, widening towards the mouth and slightly constricted behind the peristome, subangulated round the slightly excarated umbilicus. A perture suborate, oblique, margins approaching; peristome white, a little thickened, and reflexed ; upper margin arcuate, outer and basal rounded, columellar triangularly dilated abore and a little orerhanging the umbilicus. Diam. maj. 14.5 , min. $12 \mathrm{~mm}$; alt. $10 \mathrm{~mm}$.

Hab.-Olsen's Cares, Rockhampton, Queensland.

Type in Dr. Cox's collection. Somewhat similar in shape to C. exilis, but more depressed and with the hair-scars less crowded; the margins of the peristome are more approaching, and the umbilicus is a little wider and more excarated.

Chloritis aicrodrpald, n.sp. Pl. XXI, Figs. 6, $a-d$.

Shell narrowly umbilicate, globosely turbinate, finely irregularly striated and decussated with wary incised spirals, dark corncous abore, paler beneath. Spirc conical, apex obtuse, suture deep. Whorls 4 , globose, increasing rapidly, the last dilated torards the mouth, descending suddenly and deeply in front, obscurely angulated round the narrow deep umbilicus. Aperture suboral, oblique, margins approaching, united by a thin callus; peristome white, a littlo thickened and reflexed, margins erenls rounded, columellar margin broadly triangularly dilated, more than half covering the umbilicus. Diam. maj. $21 \cdot 5$, min. $18 \mathrm{~mm}$; alt. $17 \mathrm{~mm}$.

Mab.-Barrier Range, North-West Australia.

T5pe in Dr. Cox's collection. 'I'he only species to be compared with C. micromphala is C. Blackmani, but the globose whorls, the broader base, the more dilated last whorl, the more approximate margins of the peristome, and the absence of hair-scars at once scparate the new species from its ally; the more broadly dilated columellar margin of the peristome and the more corered umbilicus are also differentiating characters.

Chlonitis Poorei, n.sp. Pl. XXI, Figs. 7, $a-d$.

Shell moderately umbilicate, globose, thin, pale ochreous, a little shining, irregularly striated, very densely covered with minute hairscars arranged in quincunx. Spire conical, apex obtuse, suture channelled. Whorls $4 \frac{1}{2}$, increasing regularly, tumid, shouldered near the suture, somewhat compressed at the periphery, obtusely angulated round the deep umbilicus, which is slightly excarated; last whorl slightly dilated towards the mouth, scarcely descending in front. Aperture subcircular, oblique, margins convergent; peristome pale fulrous, thin, a little expanded; margins evenly rounded, columellar triangularly dilated and reflexed, covering half the umbilicus. Diam. maj. 12.5 , min. $10.5 \mathrm{~mm}$; alt. $9.5 \mathrm{~mm}$. 
Hab.-Cardwell, Queensland.

Trpe in my collection. This species and the next two, together with C. Blackmani, are closely associated on account of the excessively crowded and minute hair-scars, this character rarying in an inverse ratio to the size of tho shell. $C$. Poorei is distinguished from $C$. Blackmani and $C$. Thales by the narrower umbilicus and the deeper suture.

\section{Chlortris Thales, n.sp. Pl. XXI, Figs. 8, $a-d$.}

Shell narrowly umbilicate, globose, thin, translucent, corneous, a little shining, irregularly striated, rery densely covered with excessirely minute hair-points arranged in quincunx. Spire conoid, apex obtuse, suture deep. Whorls 5, convex, obtusely angulated near the suture and round the narrow umbilicus, rounded at the periphery and below, increasing regularly, the last rapidly, slightly dilated towards the mouth, and a little descending in front. Aperture subcircular, oblique, margins convergent; peristome thin, corneous, slightly expanded; margins evenly rounded, columellar margin triangularly dilated and reflexed, more than half covering the umbilicus. Diam. maj. $14 \cdot 5$, min. $12.5 \mathrm{~mm}$.; alt. $12 \mathrm{~mm}$.

IIab.-Rockingham Bay, Queensland. Somerhat like a small C. Blackmani, but with narrower umbilicus; the whorls are more tumid, flattened near the suture; the hair-scars in C. Blackmani are still more crowded than in the present species.

Chloritis misseld, n.sp. Pl. XXI, Figs. 9, $a-d$.

Shell moderately umbilicate, depressed conoid, thin, pale corneous, finely plicate-striate, densely corered with rather large hair-scars arranged in quincunx. Spire low conical, apex obtuse, suture channelled. Whorls 4, convex, increasing regularly, the last rather suddenly, widened towards the mouth and constricted behind the peristome, slightly compressed below and subangulated round the excavated umbilicus, shortly deflexed in front. Aperture suborate, oblique, margins approaching; peristome thin, scarcely reflexed, margins evenly rounded, columellar slightly dilated and impinging upon the umbilicus. J)iam. maj. 8.5, min. $7 \mathrm{~mm}$.; alt. $5 \cdot 5 \mathrm{~mm}$.

IIab.-Queensland.

Tspe in Dr. Cox's collection. The smallest member of the group, and allied to $C$. Poorei, but much smaller and much more depressed; it somewhat resembles $C$. Buxtoni in shape.

Chloriris obsubila, n.sp. Pl. XXI, Figs. 10, $a-d$.

Shell narrowly umbilicate, turbinately depressed, dull ochreouscorneous, finely plicate-striate, with microscopical wrinkled spirals under a deciduous relrety cuticle. Spire conoid, apex granulate obtuse, suture rather shallow. Whorls 5, convex, increasing regularly, the last rather suddenly, obscurely angulated above the periphery, a little widened towards the mouth, scarcely constricted behind the peristome, very shortly deflexed in front, slightly compressed below, and obscurely angulated round the narrow 
umbilicus. Aperture orate-lunate, oblique, margins conrergent peristome thin, whitish, slightly reflexed, margins evenly rounded, columellar triangularly dilated and slightly orerhanging the umbilicus. Diam. maj. 18, min. $15.5 \mathrm{~mm}$; alt. $12 \mathrm{~mm}$.

IIab.-Australia.

Trpe in Dr. Cox's collection. In shape it resembles C. mucida, but it is smaller and has a slightly narrower umbilicus, while the aperture is less dilated transversely. No trace of hair-scars can be detected, although the periostracum is quite fresh.

Cinlonttis Etraensis, n.sp. Pl. XXI, Figs. 11, a-d.

Shell imperforate, depressed conoid, dull, dark corneous, very finely and regularly striated, corered with very minute and crowded short bristles. Spire much depressed, apex low, suture rather shallow. Whorls 4 , increasing regularls, the last rather suddenly, the carlicr ones a little conrex, the last compressed above, obtusely angulated abore the periphers, compressed below, becoming inflated towards the mouth and slightly constricted behind the peristome, obtusely angulated round the very small umbilical depression. Aperture subelliptic, little oblique, margins approaching, united by a thin callus; peristome whitish, becoming fulvous at the edge, a little thickened, expanded and reflexed; upper margin ascending at first, then slightly curved, outer rounded, basal nearly straight, columellar obliquely ascending, triangularly dilated and reflexed, entirely corering the umbilicus. Diam. maj. 13 , min. $11 \mathrm{~mm}$; alt. $8 \mathrm{~mm}$.

IIab.-Etna Bay, Dutch New Guinea.

Type in Mr. Ponsonby's collection. C. AEtnaensis differs from C. telitecta in the completely covered umbilicus, the more depressed spire, and in having the aperture more contracted laterally. From C. eurychasma it may be distinguished by its smaller size, the com pressed whorls, the supra-peripheral angulation, the less oblique and more contracted aperture; the last whorl is also more dilated and constricted, and descends less in front; the columellar margin is less dilated, and the bristles are finer and more crowded. 